\title{
The Application of Multi-Cultural Elements in the Teaching of Islamic Education
}

\author{
Noraini Binti Omar \\ Department of Methodology and Educational Practice, Faculty of Education, \\ National University of Malaysia, 43600 NUM Bangi, Selangor, Malaysia \\ Mohd Aderi Che Noh \\ Department of Methodology and Educational Practice, Faculty of Education, \\ National University of Malaysia, 43600 NUM Bangi, Selangor, Malaysia \\ Email: aderi@ukm.my \\ Mohd Isa Hamzah \\ Department of Methodology and Educational Practice, Faculty of Education, \\ National University of Malaysia, 43600 NUM Bangi, Selangor, Malaysia \\ Email: cher@ukm.my \\ Hasnan Kasan \\ Centre for General Studies, National University of Malaysia, \\ 43600 NUM Bangi, Selangor, Malaysia \\ Email: hasnan@ukm.my
}

Doi:10.5901/mjss.2014.v5n16p403

\section{Abstract}

The concept of multicultural is a concept that has existed along with the teaching of Islam as conveyed by the Prophet Muhammad p.b.u.h. Islam as a concept incorporates the concept of openness, and acceptance of many races, religion, culture and faith. Islam is not limited to "Religion" in the normal sense of the word, and in fact is a complete way of life, its presence is a gift from Allah (rahmatan lil alamin), which can be used for the benefit of man on the earth. Islam is a religion that acknowledges the existence of other religions as sunnatullah. In Islam there is no distinguishing between skin colours as the reality of the creation of man begins from one man, Adam. The creation of man from different nationalities and families was to create the basis for getting to know and helping each other. The culture of diversity in the implementation of Islamic laws is evidence of Islam's acknowledgement and celebration of multicultural aspect. Hence this paper will explain as a preliminary view on the importance of Islamic Education teachers to understand the concept of cultural diversity that exists in schools especially in a multiracial society like Malaysia. Exploring the understanding of teachers toward the concept of diversity is hoped to contribute to the practice in the classroom. This preliminary study was used an interview methods. It is hoped that an understanding of this diversity will at least be able to overcome any misperception and misunderstanding between Muslims and non-Muslims. The most important is this understanding will form the basis for unity among the plural society in Malaysia.

\section{Introduction}

The Prophet p.b.u.h. had outlined policies in welcoming people whether Muslims and non-Muslims. The practice of mutual respect, tasamuh (tolerance) in interaction, and preference for justice, has made Islam and its followers respected and admired (Mahmod Zuhdi 1999; Mat Saad 1999; Ramli 2003). The concept of multiculturalism is indeed a concept that has been considered as sunnatullah (al-Nahl 16:9). Islam teaches us that humans are descended from a sole lineage (Ramli, 2003). Islam is a religion that recognizes and considers the whole of humanity as one family, originated and descended from one mother and father (al-Nisa'4: 1), of one ummah (al-Baqarah 2:213, Al-Anbiya '21: 92, al-Mu'minun 
23:52), and teaches us to get to know and help each other (al-Hujuraat 49:13).

\title{
2. Islam and Cultural Diversity
}

Allah the Almighty has subtly incorporated the concept of cultural diversity in the deeds of a Muslim. For example, the difference between the sects (school of thought) in figh also shows how Islam teaches its ummah to accept and celebrate the diversity in how their deeds are performed individually, such as the practice of prayer, pilgrimage and so on. Here it is clear that Islam is inclusive and not exclusive in nature. Islamic teachings are not rigid or owned by one group alone but flexible. This is because Islamic teachings are flexible in terms of its implementation although the rule behind it remains fixed. This is similar to the creation of man. As Allah the Almighty says:

\begin{abstract}
"O mankind! Surely We have created you from a male and a female and made you into nations and tribes that you may know (and be friendly with the other). Verily, the most honourable of you with Allah is that believer who has at-Taqwa (not one who has more in his lineage or race). Verily, Allah is All-Knowing, All-Aware (of your circumstances and deeds)."
\end{abstract}

(Al-Hujuraat (The Dwellings) 49:13)

Ibn Kathir (2007) in his interpretation explained that indeed man is equal before God. There is not a single nation that has an advantage over others. But the honour of a person in the eyes of God is measured from his faithfulness. According to Ramli (2003), this verse also shows the original concept of the creation of man, from the descendants of Prophet Adam p.b.u.h. This awareness about the origins from one source, provides a clear lesson to mankind that wherever they may be, their humanitarian duties and responsibilities are the same. This point is also mentioned in the hadith of the Prophet Muhammad p.b.u.h., narrated by Muslim: "Allah will not look at your forms and possessions, but He looks at your heart and your deeds." Imam Ahmad also narrated: "Behold thou art no superiority a red-skinned and darkskinned save from the way you glorify Him by piety to God the Almighty."

According to Ghazali Basri (2003), conceptually (al-Hujuraat 49:13) it is shown that the existence of different ethnic, racial and tribal is the nature of the Divine. Therefore Muslims must respect the existence of other ethnic groups and races and respect for their rights. Muslims are also required to love towards each other as required by the phrase "li ta'arafu" which means that you get to know each other.

Al-Ghazali (1988) explained that to honour others regardless of gender, race, religion and status is a symbol of the moral strength of a society. The arrival of Islam eradicates the differences in status of man. (Mohammed Shadid 1994). No one is in a better position than the other because of his wealth, status, lineage and tribe over another. Islam recognizes the nature of human grouping into families, tribes and nations, as an order that had been created and defined by Allah (Hasan Langgulung 1995). The Apostle p.b.u.h. said: "Each of you was from Adam whereby Adam was from clay". Allah the Almighty made it compulsory for man to enslave himself to Him or worship Him, both in relationship with God or a relationship with humans so that the well-being exist in human life.

In this matter, Islam has outlined the method of man's relationship with God is to carry out worship in its specific meaning, while the relationship between man and another is to form muamalat (interaction or transactions). "Khassah" (specific) acts of worship is mentioned as religion in the academic sense and muamalat is what referred as social, the interaction that forms society (Sidi Gazalba 1977). This is because Islam is diin, not only to regulate human relationships with God (religion), but also regulate human relationships with "hablu minan-nas". The dinn of Islam therefore organized man's life and divide it into two, his life within his relationship with God, what was considered as "religion", and his relationship with mankind, which was termed as "culture".

Mohd Kamal Hassan (1980) had also explained, in line with the concept of mankind as a servant to the Almighty, and from one lineage, the basis of human relationship is brotherhood, cooperation and a desire to help each other. Feuds, conflicts and unfair competition must be contained to ensure that peace can be preserved in personal relations. In this matter, the prophet Muhammad p.b.u.h. when he conquered Mecca without bloodshed, declaring to the public:

"O people! Allah has eliminated the feeling of superiority defended by some during the Jahiliyyah (Days of Ignorance) times and has eliminated any claim to higher breeding by relying on lineage. Indeed there are only two kinds of people only: the good, glorified by God and the evil, cursed in the sight of God. All men are sons of Adam and God created Adam from clay."

Islam had further given freedom of religion to mankind. As was declared by Allah the Almighty which means: 
"There is no compulsion in religion, verily, the Right Path has become distinct from the wrong path." (Surah al-Baqarah (The Cow) 2:256)

For example, the Constitution of Medina (the Medina Charter) which was signed between the Apostle p.b.u.h, the Mu'min, and Muslims from Quraisy with the people of Yathrib and their followers, with the Jews, and they were neighbourly since he arrived in Medina. This was clearly stated in Clause 25 the Constitution of Medina that is:

"25 The Jews of the Banu 'Auf are one community with the believers (the Jews have their religion and the Muslims have theirs), their freedmen and their persons except those who behave unjustly and sinfully, for they hurt but themselves and their families." (Mat Saad 1999).

Thus we can conclude here that the Charter itself had guaranteed equality of rights and liabilities of all individuals and also guaranteed the freedom of belief, faith and customs for all regardless of race or religion (Ahmad 1999). Jews were also required to issue expenses, together with the Muslims while there was still a war. They should also be helping each other in the face of the enemy, and were mutually obliged to advise each other to do a good deed and avoid all sin (Ahmad 1999).

\section{The Role of Islamic Education}

In the context of human relations, cultural diversity and pluralism of the society that exists necessarily has implications for administrative and educational system of a country. Similarly, in Malaysia, what is certain diversity also has implications on the practice of teaching and learning in schools.

The aim of Islamic education is the translation of the Islamic philosophies itself. Therefore, it must be recognised that the universal values of Islam can be shared by every religion and race on earth, in line with the concept of rahmatan lil alamin. Islamic education is seen as a medium to integrate this diversity. This is because Islamic education is the education of values (PPK 1991) and the values brought by Islamic education is sourced from the Quran and Sunnah. Its function is to develop behaviours, skills, personality and outlook on life as a servant of God for self, society, environment and country.

Cultural diversity in education can occur through a variety of dimensions including intelligence (intellectual), gender, race, ethnicity and family background. Therefore, this diversity affects on a student learning style and culture. Thus in dealing with this diversity, teachers need to be wise in giving a fair education (educational equity) to students as is desired by the government. The teachers' wisdom in managing the situation and provide activities that will foster an appreciation of the values of unity, can create understanding, reduce polarization, and change students' perceptions about race relations, especially in the era of globalization (Holton 1998) in Ali Seman (2010).

Islamic Education subject teachers should impart respect or social values to students, so they can respect the culture and practices of other ethnic groups. Ab.Halim \& Azhar (2006), also emphasized that all students should be educated to recognize the cultural practices of other ethnic groups. This is because an understanding of the value of racial togetherness, religious and cultural differences will be able to avoid misunderstanding and thus foster a harmonious life.

Understanding of the religious and cultural differences should be stressed to the students as they are the heirs to the leadership of the country. The survival and continuity of the national unity integrity is based on the belief that our diversity is a source of strength rather than weakness (Datuk Seri Najib Tun Razak, 2012). Similarly, an understanding of this diversity is not only for academic purposes alone but also to foster a sense of unity among students of many races (Abdul Razaq et al., 2010), and can avoid the occurrence of events which may lead to conflict and misunderstanding among the public, especially the people of Malaysia which consist of various races. As a practitioner of Islamic education in the school curriculum, do IET (Islamic Education Teacher) or GPI teachers have competence in teaching a class with diverse cultures? Here, the researcher has provided some Western scholars' views, in championing multicultural education.

According to Blake (2009) and Diller \& Moule (2005), as practitioners of the curriculum, teachers should have two skills in teaching practices which characterized by various cultures. The first is the complexity of awareness and sensitivity. This means that teachers should have be sensitive towards the diversity in the classroom, including an awareness of their own and others as cultured human being, whether relating to diversity of religion, culture, ethnicity, language, economic status of the student and the student background.

The awareness of the teachers in creating a learning environment that is sensitive to all students, including through the use of teaching aids, method of teaching and the affirmation is important. From the study by Najeemah (2005), it has 
found that teachers with more than 10 years experience, do not practice and do not have sensitivity to the diversity, especially teachers who live in a homogeneous society. In fact these teachers felt that they did not need to change their existing practices, and were comfortable with existing practices used. Diversity issues for these teachers are not considered as important.

Second, the teachers need to master the various areas of knowledge and skills that enable multi-racial teaching. In this matter, as teachers, we must have skills in selecting, developing and applying strategies to assist delivery in the classroom. Mastery in terms of equity pedagogy is to enable all students in the room to get a fair chance in terms of service, knowledge and skills presented. Skills and knowledge here include teachers' attitudes, which is, do teachers have a positive attitude towards the issue or otherwise?

Garmon (2004) in Salasiah (2012) also outlined six characteristics of teacher competency in the practice of application of multi-cultural elements. The characteristics outlined by Garmon also had similarities with Blake 2009, and Diller \& Moule, 2005. Among the things are, (i) openness attitude in diversity, (ii) awareness and self-reflection, (iii) a commitment to social justice, (iv) intercultural experience, (v) experience of support group, and (vi) the educational experience.

As a pioneer in the concept of multicultural education, Banks (2005) suggested some of the practices that can be done to carry out education in cultural diversity in schools as follows:

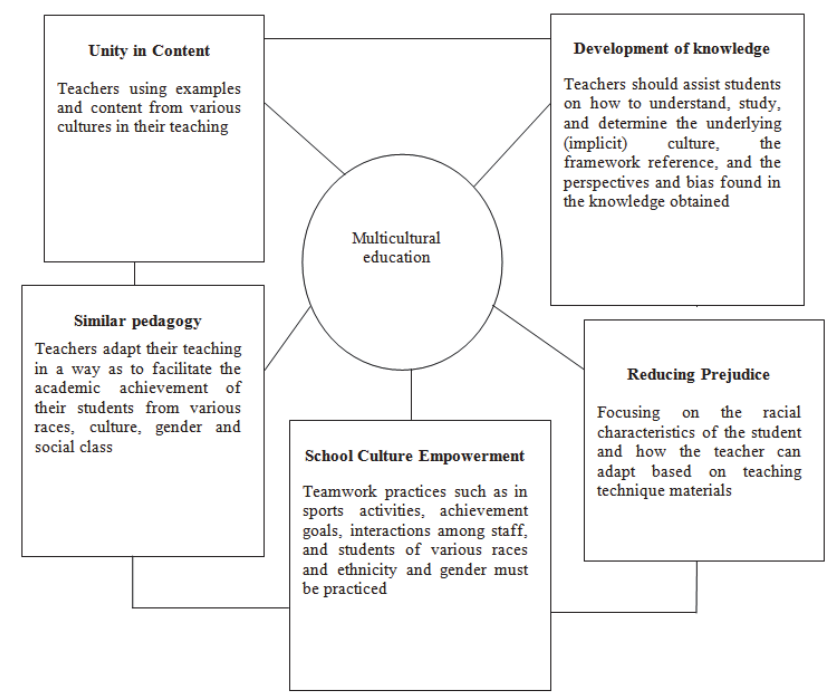

Diagram 1.4: Multicultural Educational Dimension By Bank \& Banks (2005)

Firstly, content integration: Teachers can use data, information, examples and content from various cultural sources during the process of teaching and learning, especially in explaining the main concepts, principles and theories on discipline. The use of teaching aid materials must contain the elements of cultural diversity. As an example, interaction between various races with materials that can be used for the student's various skills. This is where the values of respect, cooperation, interaction between various ethnicities, can be implemented.

Secondly, the knowledge development process: At this stage requires the teacher to assist the students to understand, study, and determine the underlying (implicit) culture, the framework reference, the perspectives and bias in the discipline of knowledge built. While following the process of teaching and learning in the classrooms, the student can identify and discuss the cultural issues that relate to the topic and contents studied.

Thirdly, prejudice reduction: To reduce prejudice teachers need to focus on the racial characteristics of the student and how the teacher can modify it based on the teaching materials and technique. Prejudice and bias against a particular race is dangerous because it can lead to long-lasting misunderstanding. Through the third dimension, all teaching and learning activities as well as activities carried out by the teacher must be able to shape a positive attitude among students especially with regard to the differences in religion, racial and cultural practices of each student. This is due to every student who comes to school has different cultural background, as well as brings with him prejudices and stereotypes 
about others. Therefore, materials and teaching tools such as reference books and audio visual featuring positive practices in multicultural society can be used to develop a more open attitude among students especially to interact with other ethnic and cultural groups exist in the school environment. The use of this material must be continuously and creatively.

Fourth, equity pedagogy: Teachers can modify the teaching in ways that can facilitate the academic achievement of students from different racial, cultural, gender and social class. This dimension stressed that the method and style of teaching whether the curriculum and co-curriculum in school, should be in line with the issues and needs of a multicultural society . This is due to the PPB Pedagogy emphasized in increasing student academic achievement and personal development as a whole, regardless of race, culture, gender and social class. Hence, the Islamic Education Teachers need to select and identify the teaching methods appropriate to meet the needs of students. Islamic Education Teachers can also modify certain rules to meet the students who have varying degrees of ability and intelligence.

Fifth, an empowering school culture and social structure: At this stage, teamwork practices such as sports activities, goal achievement, and interaction among staff and students from different race, ethnicity, and gender groups must be practiced. In the last dimension, Banks (1991) emphasized on the function of school organizations, in particular administrators, teachers and students to create a school culture that can strengthen the relationship and interaction with the community outside the school. With this interaction, academic achievement and student participation without distinguishing cultural background, ethnicity, gender and language can be achieved.

\section{Conclusion}

The teacher's role is very important in applying the values of cultural diversity among students, in accordance with the education system in Malaysia, and is the preliminary platform to inculcate values such as tolerance, cooperation, and mutual respect between the various races among students. The teachers' understanding of different cultures and skills in arranging and apply teaching strategies are necessary for students to understand the concept of culture diversity. The student's full immersion and appreciation is necessary so that the desire to get a fair education is instilled in students and thus the desire to foster unity will be achieved.

\section{References}

Al-Quran Al-Karim.

Abdul Razaq Ahmad, Anisa Saleha, Zalizan Mohd Jelas \& Ahmad Ali Seman. 2010. Kepelbagaian Pelajar Dan Sekolah: Satu Kajian Kes di Negeri Pahang (Diversity of Students and School: A Case Study in Pahang). Malaysian Journal of Education 35(2): p. 8795.

Ahmad Ali Seman, Zahara Aziz, Abdul Razaq Ahmad. 2010. Keberkesanan pendekatan berasaskan kepelbagaian budaya terhadap integrasi nasional dalam pelajaran Sejarah (The effectiveness of the approach based on the cultural diversity of the national integration in History subject). Proceedings on Postgraduate Seminar. Kuala Lumpur: Faculty of Education, National University of Malaysia.

Ahmad bin Mohammad Ibrahim (edt.) 1999. Prinsip-Prinsip Perlembagaan Islam Dalam Perlembagaan Malaysia, Prinsip-Prinsip Pemerintahan Dalam Masyarakat Majmuk (Constitutional Principles of Islam in the Constitution of Malaysia, the Principles of Governing Plural Society) (p. 145-171). Kuala Lumpur: Institute of Islamic Understanding.

Al-Ghazali. 1988. Ihya' Ulumuddin Jiwa Agama. Translt. Tk.Hj Ismail Yaakub Sh. Kuala Lumpur: Victory Agensi.

Banks James A., Cherry A.McGee Banks. 2005. Mutlicultural Education Issues and Perspectives. United States of America: John Wiley \& Sons, Inc.

Blake M.B. 2009: Operation 2014: Development. Eight Edition. Illinos Statement University. United State of America: Pearson Education, Inc.

Diller, J.V., \& Moule, J. 2005. Cultural Competence: A Primer for Educators. Toronto, CA: Thomson Wadsworth.

Ghazali Basri. 2003. Pendidikan silang budaya menurut perspektif Islam: satu pandangan awal (Cross-cultural education from Islamic perspective: a preliminary view). Journal of Islamic Studies :1-13. Kuala Lumpur: College of Dar-Al-Hikmah.

Hassan Langgulung. 1995. Pendidikan Islam Dan Peralihan Paradigma (Islamic Education and the Paradigm Shift). Shah Alam: Hizbi.

Ibu Kathier. 2007. Terjemahan Ringkas Tafsir Ibnu Kathier (Brief Translation of Ibnu Kathier Tafseer). Translt. H.Salim Bahreisy, H.Said Bahreisy, Abu Ezzat Al Mubarak, Himmatun Rofiah (edt). Vol.7. Kuala Lumpur: Pustaka Jiwa.

Mahmood Zuhdi Hj Ab Majid. 1999. Pemerintahan dalam masyarakat majmuk: huraian berasaskan al-Quran dan al-Sunnah (Government in a plural society: description based on al-Quran and al-Sunnah). Prinsip-Prinsip Pemerintahan Dalam Masyarakat Majmuk (Principles of Governing in a Plural Society) (p. 1-36). Kuala Lumpur: Institut Kemajuan Islam Malaysia.

Mat Saad Abdul Rahman (pnyt.). 1999. Kedudukan Bukan Islam Di Dalam Sejarah Pemerintahan Islam (Position of Non-Muslim in the History of Islamic Government). Prinsip-Prinsip Pemerintahan Dalam Masyarakat Majmuk (Principles of Governing in a Plural Society) (p. 83-118). Kuala Lumpur: Malaysian Institute of Islamic Understanding. 
Mohd Najib Tun Razak. 2012. Petikan Ucapan Laporan Pencapaian ETP. Siaran Langsung TV3. April 2012 (Extract of Speech on ETP Achievement Report. Live Broadcast by TV3. April 2012).

Mohd.Kamal Hassan. 1980. Nilai-Nilai Universal Islam Tentang Kesejahteraan Masyarakat (Islamic Universal Values on Social Harmony). Kuala Lumpur: Malaysia Ministry of Education.

Muhammad Shadid. 1994. Metodologi Al-Quran Dalam Pendidikan (Al Quran Methodology in Education). Transltn. Osman Hj Khalid. Bangi: National University Malaysia

Najeemah Md.Yusof. 2006. Konsep Pendidikan (Education Concept). Kuala Lumpur: PTS.

Pusat Perkembangan Kurikulum. 1991. Nilai Murni (Moral Values). Kertas Berkala (Periodical Paper). Kuala Lumpur: Pusat Perkembangan Kurikulum.

Ramli Awang. 2003. Islam Alternatif Perpaduan Sejagat (Islam the Alternative for Global Unity). Johor Darul Takzim: Universiti Teknologi Malaysia.

Salasiah Hashim. 2012. Kompetensi, Sikap Dan Kesedaran Guru Pra Sekolah Dalam Pengajaran Multibudaya. (Competency, Attitude and Awareness of Pre-School Teachers in Multicultural Teaching). Master of Education Thesis, Faculty of Education. National University of Malaysia.

Sidi Gazalba. 1977. Pandangan Islam Tentang Kesenian (Islamic View on Arts). Kuala Lumpur: Pustaka Antara. 